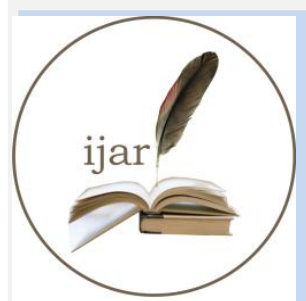

ISSN NO. 2320-5407

\section{Journal Homepage: -www.journalijar.com INTERNATIONAL JOURNAL OF ADVANCED RESEARCH (IJAR)}

Article DOI: 10.21474/IJAR01/1386

DOI URL: http://dx.doi.org/10.21474/IJAR01/1386
INTERNATIONAL JOURNAL OF ADVANCED RESEARCH (JJAR)

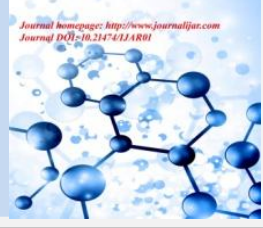

RESEARCH ARTICLE

\title{
THE IMPACT OF USING GEOGEBRAPROGRAM ON THE ACADEMIC ACHIEVEMENT IN MATHEMATICS AMONG FEMALES SECONDARY STUDENTS IN JEDDAH - SAUDI ARABIA.
}

"Fawziah D. AlMughamisi

The thirty-seven secondary School - Jeddah - Kingdom of Saudi Arabia.

\section{Manuscript Info}

Manuscript History

Received: 15 June 2016

Final Accepted: 16 July 2016

Published: August 2016

Key words:-

lack of technology, teaching,

mathematics, GeoGebra, Saudi Arabia.
Abstract

Aim: To assess the impact of using modern mathematical software on the academic achievement in mathematics among females secondary students.

Methods: A descriptive study, used interview questionnaire to assess students opinions about studying mathematics using technology. 25 students of 37th girls secondary school were selected by random sampling. This study was conducted in the 37th girls secondary school only one first semester of academic year 2011-2012. (SPSS) program was used for data analysis.

Results: $68 \%$ of students confirmed that using modern technology helps them in understanding Math better than Traditional teaching methods. Changing teaching methods to modern ones helps $64 \%$ of students who confirmed that. There is almost a consensus from sample members that their academic achievements enhanced after a while of using modern software in studying upon to $58 \%$ of sample members.

Conclusion: Using modern mathematical software has positive effects on the academic achievement in mathematics.

Copy Right, IJAR, 2016,. All rights reserved.

Corresponding Author:-Fawziah D. AlMughamisi.

Address:-The thirty-seven secondary School - Jeddah - Kingdom of Saudi Arabia. 


\section{Introduction:-}

Mathematics educators and those who are interested in teaching mathematics considered it as one of the most important tools to organize ideas and to understand the environment around us, as it helps individuals to understand their living environments and control it as well [1].

Mathematics development and enhancement comes through our sensory experiences in realityor through our needs and any other motivators [2].

Educators realized the need for educational aids to enhance teaching process while the traditional educational methods like memorization to recall the demonstrated information which is not enough to solve the daily student's mathematical problems in order to face information technology revolution and globalization.So finding new educational resources to be added to traditional school book is highly recommended [3].

Using technology in educating mathematicscan improve the mathematical ideas visualizing and understanding of students from diverse perspectives. On the other hand, using technology in teaching helps in meeting students' needs, and easing learning difficulties. If we keep in mind that students are easy to be distracted by surrounding environment, computer environment can be usefulespecially because it limits the user access to keep him in the required area of education [4-5].

Computer programs which were designed for educational purposes must be expert programs which mean that the software must be able to solve problems, and suggest alternative solutions.In the currentstudy aimed to assess the impact of using modern mathematical software on the academic achievement in mathematics among females secondary students, and "GeoGebra" software was used as an example of these software used for teaching mathematics [6-8].

\section{Research Problem:-}

One of the main reasons of utilizing modern technology in teaching and learning mathematics is the big positive impact on teachers and students in studying math, more over that it reinforces our schools to follow the revolution of information technology. During this research we noticed lowness of students grades in mathematics and this is what made researcher to use technology in the educational process of mathematics hopefully it will show better results in student's grades.

Mathematics as a primary subject in the Saudi educational system in all levels starting from primary schools and ending by universities. Learning mathematics is a problem for many students, however it is one of the main components of student's educational triangle (math, science and English), and the real reason of that problem may be thelack of utilizing technology in teaching mathematics.

The current study was established to find solutions, to improve of the student's grades in mathematics and to develop student's skills in mathematics.

\section{Research Objectives:-}

1. To assess the effect of using teaching software on the educational level in mathematics of students in the 37th girls secondary school.

2. To determine the efficiency of using teaching software in enhancing educational level in mathematics of students in 37th girls secondary school.

3. To Compare between students results who studied mathematics using traditional methods and teaching soft ware method.

\section{Educational technology:-}

Educational technology is effective for learning. As a concept, it concerns an array of tools, such as media, machines and networking hardware, as well as considering underlying theoretical perspectives $[9,10]$.

\section{The importance of using modern technology in education:-}

Educational technology enthusiasts find that the use of the technology will lead to [11]: 
1. Improve the quality of education and increase its effectiveness, this improvement caused by:

1. Solve the problems of overcrowding in classrooms and lecture halls

2. Face the shortage of qualified faculty and supervisors.

3. Take into account individual differences among students.

4. Reduce illiteracy, which stand in the way of development in various fields.

5. Train teachers in the areas of setting goals, preparing teaching materials and teaching methods.

6. Implement the modern educational vision of making the learner the axis of the educational process.

7.

2. Attract students attention and feed their needs to learn, diversity in educational aids help students to get different experiences and this is what student find interesting and achieve their goals.

3. Lead to avoid misunderstanding of words and expressions of teachers, diversity of educational media give the expressions additional diminutions which make students closer as much as possible to concepts in teacher mind.

4. Educational technology increases the students' positive participation in the educational process. If the teacher employed the educational aids in the right way by specifying and listing goals of using the educational aids then, students positive participation will increase getting new experiences, enhancing mandating and accurate observation and follow scientific thinking in solving problems.

This method leads to enhance the quality of education and increase students' academic achievements. For example, involve students in selecting the method to reach the answers of the problems just like watching educational videos to approach the solution. Also using maps and globes in experiences, usually in schools teachers use these aids for demonstration only while it's much better to let students use these aids under teacher supervision to gain positive participation in new experiences.

5. Lead to developing the abilities of students in scientific thinking and critical thinking to solve problems and organizing ideas.

6. Achieve modern education aiming to improve new orientations to enhance behavior.

Moreover, utilizing technology in education to improve student experiences to be ready to learn, Edgar Dale mentioned in his "cone of experience" that the experiences made by imaginations came at the top of the cone while experiences made by doing things take the bottom of the cone. Therefore, we can say student will be ready for learning as much as they participate in doing experiences and vice versa.

Also, these techniques help in creating diversity in teaching methods which fill the gap of individual differences of students in the classroom and researcher added "there is real enhancement in perceptual and improvement in understanding, memorizing and recalling experiences. Improvement in verbal fluency caused by continuous listening audio and video clips and extensive reading, as it increases students positive attitudes and interest in the subject through videos and audio clips".

7. Face educational evolvement philosophy and changing in teacher role: "education aims to teach individuals the required experiences and orientations to help them to success in life and face future challenges.Traditional educational models can't achieve that, but by providing experiences and sources of learning individuals will be able to face all challenges and future changes.So, making the educational aids available will diversifies experiences for life long.

From here is established the concern in education to prepare individual for life and use all educational communication medias including social media.

In this framework the teacher job changed from traditional role of indoctrination to a job with new roles, functions and experiences to be performed in light of education evolvement. So, it became referred to teacher sometimes as a man of technological education which uses all the technical means to serve the education, and became success measured by its ability to design learning situations using all means of education, and technology that will help everyone to gain experiences that qualify to meet the requirements of the age. And it became referred to the teacher as well as a designer for the environment that achieve learning.

8. Importance of educational aid in facing modern changes: that "the world passes through a lot of changes in all life fields and that affected education on all levels. Also, educators demand more skills, and abilities to face the 
modern methodologies and challenges to push education to the level that allows learners to develop the community.

\section{Computer in Education:-}

Studies show that the ability to utilize computers in educating mathematics, UNSCO report in 1986 mentioned that computer became available in a lot of schools around the world.

Using computer in education mainly focuses on presenting examples and students interact with changes and questions.

Using computer in teaching and learning process improves the chances to prepare students for a world built on technological education core, and help them to be familiar with processing the information and realizing computer limits. Quality of education will be enhanced using computers by helping learner to get instant feedback, motivation and consistence in educational environment [12].

Feeling of success, control of learning environment and motivation to use computers. These three reasons make possibility of success better in using computers in learning mathematics. Also, computerswere used to run a program aiming to train students with low academic achievements to face their learning difficulties. Programs like games and educational software are scalable started by low levels gradually increase the difficulty which increase the chances of learning more skills of mathematical problem solving [13].

\section{Computer as teaching aid of mathematics:-}

NCTM (National Council of Techers of Mathematics) approved teaching mathematics using technology approach, this approach depends mainly on utilizing technology in teaching and learning mathematics. Computers and calculators come on top of the list of equipment that effectively used in education. Students who studied using the two equipment showed great academic achievements that refer to efficacy in organizing, analyzing data and accuracy in processing mathematical problems in addition to help in research activities in all mathematics fields.

Computers and technologies related to computer became two main helping factors in secondary schools teaching process. Computers were used by teacher to provide training, exercises and tests for students and were also used to store and analyzing students' performance data and scheduling varies educational activities. Teachers and students using computer to solve problems and create typical scientific and social processes. Simulating complicated physical operations.

The reasons that increase success possibilities of using computer more than other technologies are the following [1415]:

1. Computer makes students feel of success and more experienced with dealing with computers which improve students orientations toward mathematics.

2. Control, feeling of control of educational environments is a strategy that makes students more involved in the educational process while other strategies put them in a negative position.

3. It is self-proved that is generated from students usage of computer motivates them to learn more to be creative in dealing with software or even in coding new programs which more interesting and convenient in learning new skills.

Using computers as teaching aid has a lot of educational advantages just like helping teachers in programing interesting exciting educational materials full of interactive and multimedia included animations, sounds and pictures.

\section{Types of educational software:-}

Educational software are all computerized lessons, courses, package of activities produced to achieve specified educational goals for specified students.

\section{Examples of mathematical educational software [16]:}

1. Microsoft Math 2007: It is programed to solve mathematical problems and demonstrates solving steps.

2. Universal Math Solver: It is programed to solve mathematical problems. 
3. Mathematica: It is widely used program designed to solve problem ofvarious fields like mathematics, physics and geometry, this program is cable of solving all mathematical problems, drawing graphs, solving (equations, algebra problems, Calculus and Series arrays etc.) and the ability of modifying and analyzing data.

4. GeoGebra: This program properties and advantages are as the following:

GeoGebra is educational software approved by the ministry of education in KSA. This program was developed by (Markus Hohenwarter) international members of development team work. The aim of this program is enhance the students understanding of theories and facts of mathematics through practical applications to discover the mathematical concepts by students using a group of tools designed to make the educational process more interactive.

\section{Philosophy of GeoGebraProgram:-}

The program is based on deep belief of students capability to learn mathematics if they were given the chance to learn it, and work on solving problems that fit them in levels and time. The program uses learning by practicing approach since mathematics requires a lot of practice to gain its skills and understand concepts and build relationships between these skills and concepts to drive them to conclude the following : if we give students the chance to practice mathematics starting from the level that fits him and gradually move to the next levels this make learning process possible and meet the students current skills and give students more confidence makes them reach the program slogan GeoGebra [17].

\section{GeoGebra Program Goals:-}

This program aims to [17]:

1. Help students understand and visualize concepts.

2. Help students join mathematical ideas to each other's.

3. Help students employ mathematics in daily life problems.

4. Build students self-confidence in learning mathematics.

5. Develop self-learning skills.

6. Enhance mathematical academic achievements.

7. Develop critical thinking skills.

8. Develop positive attitudes toward mathematics.

9. Give students the chance to show their best abilities.

\section{Areas covered by GeoGebra:-}

According to NCTM (National Council of Techers of Mathematics) GeoGebra covers the following area of math [18]:

1. Measurement.

2. Geometry.

3. Algebra.

* Free open source program written with Java compatible with Windows, Linux and Mac OS. Supporting more than fifty languages, available on (Online based) and OS based. The program provides workshops and sharing ability to allow team work. And it's also available on Smart phones and tablets. GeoGebra awarded by a lot of American, European awards and one of them the German award for educational software.

* The program provides a dynamic database of teaching and learning mathematics starting from prep schools level to college level in different fields of math including algebra, geometry and calculus.

* The program contains 3 windows as shown in Fig. 1:
$\circ$ Graphic View.
- Algebra View.
- Spread Sheet View.

All mathematical elements could be shown in different views (Algebra, Graphic and spread sheet) Spread Sheet view can show Algebra and Graphic views of the same problem with dynamic relationships create auto update for all

views. 
Fig. 1 :-Windows of GeoGebra Software

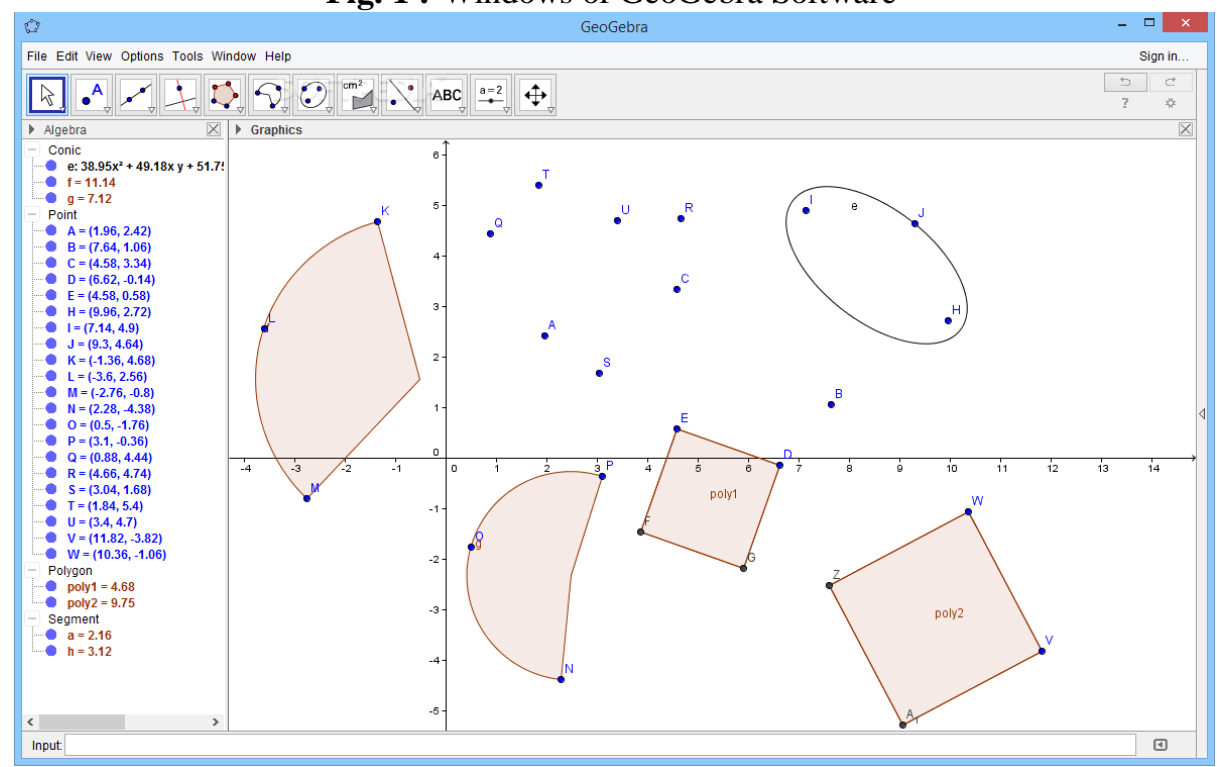

GeoGebra processes the following fields [18]:

1. Effective geometry.

2. Dots, lines (arrows), circles, functions, polygons, cones.

3. Geometry Program show in algebra method.

4. Building, parallel lines, points of intersection, midpoint, circles.

5. Measure distances, places and angles.

6. Animation.

7. Text box.

8. Text control tools.

9. Transformational geometry, translations, reflections, breadth, involved, dilate.

10. 3D pictures.

11. 2D Graphs, 3D Graphs.

12. Derivation and integration, easy and hard problems, Algebra schematic, arrays, groups.

13. Statistics, Random Numbers, probabilities, graph probabilities, prove and test theories and a lot of mathematical usages here we just show a short list.

The researcher selected this program and expected it to meet the requirements to for teaching mathematics of secondary schools students.

Elgar [19] was conducted study to examine uses of technology in secondary school mathematics instruction" the study found out the need for technology training on instructional software and budgetary problems to purchase software and upgrade existing hardware.Also,Al-Zahrani's Study [20] conducted in (2004) to assess the effect of using algebra parts in teaching mathematical expressions unit on the third intermediate grade students educational achievements in Taif' results showed difference of statistical indication between the degrees of average for experimental group and those of control group of the educational achievements at each level and this lead according to researcher opinion of the importance of involving students in using educational aids referring to the enhancement in academic achievements. Moreover, Elmanshy conducted study [21] in (1985) thatshowed that educational techniques has important role in developing the curriculum and teachers must be trained on it since these new technologies have a lot of good uses with endless benefits, and Alhatal study [22] conducted in (2011) to explore he effect of using educational computerized program in teaching math on developing mathematical thinking of eighth grade and their attitudes toward math. The study aimed to realize the effect of using educational computerized program in teaching math on developing mathematical thinking of eighth grade and their attitudes toward math, and to achieve the aim of the study by using experimental method in researching, that study targeted (977) students of eight grade in west Gaza area in the UNRWA schools and the research sample (80) students of Alshatea' girls prep school in Gaza. The sample was divided into two groups, one of them was experimental group that studied geometry units using computerized educational program and the other one was control group that 
studied the same unites using traditional method. After that the researchers applied on a sample of mathematical tests, they concluded to the following results: There are statistically significant differences at significant level $\alpha=(0.05)$ in posttest for the group of students whom involved in the experimental method, also there were statistically significant differences in average of students attitudes toward studying math and mathematical thinking with higher attitude to the experimental group in both of them. The computerized program showed high efficacy in developing the mathematical thinking of the students in the sample.

Al-Hariqi study [23] conducted in (1993) "The difficulty of using educational aids for practical education student", the study involved 54 trained students of literary and scientific specializations to show the difficulties they face in using educational aids, the results and recommendations show a difference in reaction from different speculations. Also the study showed that there are difficulties in using teaching aids related to (lack of equipment, lack of skills, lack of educational aids).

Althobyani [24] conducted in (2009) "modern Technologies reality in teaching Mathematics at intermediate stage from Mathematics teachers". The study sample consisted of all Mathematics teachers at intermediate schools in Yanbu in Saudi Arabia ( 67) teachers - the questionnaire was used as study tool, he confirmed it's correctness and stability and results of his study showed low degree of providing modern technologies in intermediate schools and high degree of difficulties that teachers see it as an obstacle for using modern technologies.

\section{Methodology:-}

Design:- and Tools:-

A descriptive study, used interview questionnaire (annex 1) to assess students opinions about studying mathematics using technology.

\section{Sample and Sampling:-}

25 students of 37 th girls secondary school were selected by random sampling.

\section{Study:- Setting:}

The37th girls secondary school in Jeddah - Saudi Arabia.

\section{Study limits:-}

Study was conducted in the 37th girls secondary school only one first semester of academic year 2011-2012.

\section{Statistical Analysis:-}

Statistical Package for the Social Sciences (SPSS) program was used for data analysis.

\section{Ethical Consideration:-}

We got all of required ethical approvals including ethical board of the Ministry of Education and informed consent of the participants.

\section{Results \&Disscusion:-}

Using Technology in teaching math helps students understand mathematics better than traditional methods. Table 1. Shows most of the students answered by somewhat agree and their percentage is $68 \%$ and $20 \%$ of them have answered Agree, while 12\% answered not agree.

Table 1:-Using technology in learning mathematics

\begin{tabular}{|l|l|l|}
\hline $\begin{array}{l}\text { Do you think that using technology in learning mathematics } \\
\text { help you to understand mathematics better? }\end{array}$ & Frequency & Percentage \% \\
\hline Agree & 5 & $20 \%$ \\
\hline Do not Agree & 3 & $12 \%$ \\
\hline Somewhat Agree & 17 & $68 \%$ \\
\hline Total & 25 & $100 \%$ \\
\hline
\end{tabular}

One of the advantages of using teaching software is enhancing students understanding of the curriculum and helping them reach the best academic achievements according to $68 \%$ of the sample members. Table 2. shows that most of 
the students answered by agree and their percentage is $68 \%$ and $24 \%$ of them have answered somewhat Agree, while 8\% answered not agree. This agrees with Elgar study [19].

Table 2:-Using teaching software helps students to understand curriculum

\begin{tabular}{|l|l|l|}
\hline $\begin{array}{l}\text { Do you think that using teaching software helps students to understand } \\
\text { curriculum and then achieve the highest academic achievements? }\end{array}$ & Frequency & Percentage \% \\
\hline Agree & 34 & $68 \%$ \\
\hline Do not Agree & 4 & $8 \%$ \\
\hline Somewhat Agree & 12 & $24 \%$ \\
\hline Total & 25 & $100 \%$ \\
\hline
\end{tabular}

Changing math teaching methodology from "Traditional" to "Modern" helps students according to $64 \%$ of sample members who confirmed that. Table 3. shows that most of the students answered by agree and their percentage is $64 \%$ and $20 \%$ of them have answered somewhat Agree, while $16 \%$ answered not agree. This agrees with AlZahrani's Study [20].

Table3:-Changing math teaching methodology from "Traditional" to "Modern"

\begin{tabular}{|l|l|l|}
\hline $\begin{array}{l}\text { Do you think that changing math teaching methodology from } \\
\text { "Traditional" to "Modern" help students in study? }\end{array}$ & Frequency & Percentage \% \\
\hline Agree & 16 & $64 \%$ \\
\hline Do not Agree & 4 & $16 \%$ \\
\hline Somewhat Agree & 5 & $20 \%$ \\
\hline Total & 25 & $100 \%$ \\
\hline
\end{tabular}

There is almost a consensus that using software in study encouragescooperating and participate with colleagues in studying Math according to $68 \%$ of the sample members. Table 4. shows that most of the students answered by agree and their percentage is $68 \%$ and $20 \%$ of them have answered somewhat Agree, while $12 \%$ answered not agree. This agrees with Elmanshy study [21].

Table 4:-Using software in study encourage students participation

\begin{tabular}{|l|l|l|}
\hline $\begin{array}{l}\text { Do using software in study encourage you to cooperate and } \\
\text { participate with colleagues in studying Math? }\end{array}$ & Frequency & Percentage \% \\
\hline Agree & 17 & $68 \%$ \\
\hline Do not Agree & 3 & $12 \%$ \\
\hline Somewhat Agree & 5 & $20 \%$ \\
\hline Total & 25 & $100 \%$ \\
\hline
\end{tabular}

There is a lack of computers in school compared to the number of students in the school there are almost consensus agreement on that. Table 5. shows that most of the students answered by agree and their percentage is $68 \%$ and $24 \%$ of them have answered somewhat Agree, while 8\% answered not agree. This accords with Alhatal study [22].

Table 5:-Lack of computers in the school

\begin{tabular}{|l|l|l|}
\hline Do you think there is lack of computers in the school? & Frequency & Percentage \% \\
\hline Agree & 34 & $68 \%$ \\
\hline Do not Agree & 4 & $8 \%$ \\
\hline Somewhat Agree & 12 & $24 \%$ \\
\hline Total & 25 & $100 \%$ \\
\hline
\end{tabular}

There is almost a consensus that they don't like using the same teaching technique by teachers according to $64 \%$ of the sample members. Table 6. shows that most of the students answered by agree and their percentage is $64 \%$ and $20 \%$ of them have answered somewhat Agree, while 16\% answered not agree. This agrees with Al-Hariqi study [23].

Table 6 :-Using the same teaching technique by teachers

\begin{tabular}{|l|l|l|}
\hline Students don't like using the same teaching technique by teachers? & Frequency & Percentage \% \\
\hline Agree & 16 & $64 \%$ \\
\hline Do not Agree & 4 & $16 \%$ \\
\hline Somewhat Agree & 5 & $20 \%$ \\
\hline Total & 25 & $100 \%$ \\
\hline
\end{tabular}


There is almost a consensus that their academic achievements have been enhanced after a while of using teaching software according to $68 \%$ of the sample members. Table 7. shows that most of the students answered by agree and their percentage is $68 \%$ and $24 \%$ of them have answered somewhat Agree, while $8 \%$ answered not agree.

Table 7:-Academic achievements using teaching software

\begin{tabular}{|l|l|l|}
\hline $\begin{array}{l}\text { My academic achievements have been enhanced after a while of using teaching } \\
\text { software }\end{array}$ & Frequency & Percentage \% \\
\hline Agree & 34 & $68 \%$ \\
\hline Do not Agree & 4 & $8 \%$ \\
\hline Somewhat Agree & 12 & $24 \%$ \\
\hline Total & 25 & $100 \%$ \\
\hline
\end{tabular}

There is almost a consensus agreed that Math became interesting subject after using software in studying it. Table 8. shows that most of the students answered by agree and their percentage is $44 \%$ and $32 \%$ of them have answered somewhat Agree, while small percentage answered not agree.

Table 8 :-Satisfactions of Math subject when using software

\begin{tabular}{|l|l|l|}
\hline Math became interesting subject after using software in studying it. & Frequency & Percentage $\%$ \\
\hline Agree & 11 & $44 \%$ \\
\hline Do not Agree & 6 & $24 \%$ \\
\hline Somewhat Agree & 8 & $32 \%$ \\
\hline Total & 25 & $100 \%$ \\
\hline
\end{tabular}

Using teaching software saves students efforts. Table 9. shows that most of the students answered by agree and their percentage is $68 \%$ and $20 \%$ of them have answered somewhat Agree, while $12 \%$ answered not agree.

Table 9:-Using teaching software save efforts

\begin{tabular}{|l|l|l|}
\hline $\begin{array}{l}\text { Using teaching software save efforts and give me space to } \\
\text { participate in disunion and asking questions. }\end{array}$ & Frequency & \\
\hline Agree & 17 & $68 \%$ \\
\hline Do not Agree & 3 & $12 \%$ \\
\hline Somewhat Agree & 5 & $20 \%$ \\
\hline Total & 25 & $100 \%$ \\
\hline
\end{tabular}

Table 10. shows that most of the students answered by Not agree and their percentage is $80 \%$ and $16 \%$ of them have answered Agree, while small percentage answered somewhat agree. Teachers do not use modern technology all the time. This agree with study of Althobyani [24].

Table 10 :-Using modern technology all the time by teachers.

\begin{tabular}{|l|l|l|}
\hline Do Teachers use modern technology all the time? & Frequency & Percentage $\%$ \\
\hline Agree & 4 & $16 \%$ \\
\hline Do not Agree & 20 & $80 \%$ \\
\hline Somewhat Agree & 1 & $4 \%$ \\
\hline Total & 25 & $100 \%$ \\
\hline
\end{tabular}

\section{Conclusion:-}

It is concluded lack of computers in the schools, using GeoGebra program in education has positive effects on the academic achievement of school students in mathematicscourses like understanding mathematics better, getting higher degrees, and encouraging cooperation and participationof students.

\section{Recommendations:-}

The Ministry of Education should exploit the results of this studyto encourage schools to use educational programs like GeoGebrathat reflected positive effects in enhancing students' academic achievements in mathematics. Further studies should be conducted on other educational programs that may enhance knowledge acquisition of school student. 


\section{References:-}

1. Ball, D.L., Lubienski, S.T. and Mewborn, D.S., 2001. Research on teaching mathematics: The unsolved problem of teachers' mathematical knowledge. Handbook of research on teaching, 4, pp.433-456.

2. Armstrong, T., 2009. Multiple intelligences in the classroom. Ascd.

3. Stigler, J.W. and Hiebert, J., 2009. The teaching gap: Best ideas from the world's teachers for improving education in the classroom. Simon and Schuster.

4. Koszalka, T.A. and Wu, C.P., 2004. A Cultural Historical Activity Theory [CHAT] Analysis of Technology Integration: Case Study of Two Teachers. Association for Educational Communications and Technology.

5. Garofalo, J., Drier, H., Harper, S., Timmerman, M.A. and Shockey, T., 2000. Promoting appropriate uses of technology in mathematics teacher preparation. Contemporary Issues in Technology and Teacher Education, 1(1), pp.66-88.

6. Hohenwarter, M., Hohenwarter, J., Kreis, Y. and Lavicza, Z., 2008. Teaching and calculus with free dynamic mathematics software GeoGebra. Retrieved May, 17, p.2010.

7. Hohenwarter, M. and Fuchs, K., 2004, May. Combination of dynamic geometry, algebra and calculus in the software system GeoGebra. In Computer Algebra Systems and Dynamic Geometry Systems in Mathematics Teaching Conference.

8. Hohenwarter, J., Hohenwarter, M. and Lavicza, Z., 2009. Introducing dynamic mathematics software to secondary school teachers: The case of GeoGebra. Journal of Computers in Mathematics and Science Teaching, 28(2), pp.135-146.

9. Richey, R.C. (2008). "Reflections on the 2008 AECT Definitions of the Field". TechTrends 52 (1): 24-25.

10. D. Randy Garrison and Terry Anderson; Definitions and Terminology Committee (2003). E-Learning in the 21st Century: A Framework for Research and Practice. Routledge. ISBN 0-415-26346-8.

11. UNESCO: international project on technical and vocational education, the manual for the preparation of prototypes for development of curricula for technical and vocational education, part 1: link the curriculum to the needs of the labour market, Jordan: Oman, 1994.

12. Chapman, D.W. and Mahlck, L.O., 2004. Adapting Technology for School Improvement: A Global Perspective. International Institute for Educational Planning (IIEP) UNESCO. 7-9 rue Eugene-Delacroix, 75116 Paris, France.

13. De Ferranti, D.M. ed., 2003. Closing the gap in education and technology. World Bank Publications.

14. Ganguli, A.B., 1992. The effect on students' attitudes of the computer as a teaching aid. Educational Studies in Mathematics, 23(6), pp.611-618.

15. Churchhouse, R.F., 1986. The Influence of Computers and Informatics on Mathematics and Its Teaching: Proceedings From a Symposium Held in Strasbourg, France in March 1985 and Sponsored by the International Commission on Mathematical Instruction (Vol. 1). CUP Archive.

16. Hohenwarter, M. and Fuchs, K., 2004, May. Combination of dynamic geometry, algebra and calculus in the software system GeoGebra. In Computer Algebra Systems and Dynamic Geometry Systems in Mathematics Teaching Conference.

17. Grandgenett, N., 2007. Geogebra. Mathematics and Computer Education, 41(3), p.276.

18. Hähkiöniemi, M., 2013. Teacher's reflections on experimenting with technology-enriched inquiry-based mathematics teaching with a preplanned teaching unit. The Journal of Mathematical Behavior, 32(3), pp.295308.

19. Elgar, E.S., 2005. An examination of the uses of technology in secondary school mathematics instruction (pp. 1309).

20. Zahrani, Khaled bin Saleh bin Ali .The impact of the use of the compulsory pieces in the teaching of mathematical expressions for third graders. Unpublished Master Thesis. 2004. Al-Manara Library of Al-Azhar University, Egypt.

21. Al-Manshi, Anissa. 1985. The role of educational technology in teacher education curriculum development, educational technology magazine. Arab Center for educational technology, Kuwait, no. 16, pp. 28-66.

22. Alhtal, Maher (2011) the effect of using software in mathematics education on the development of mathematical thinking and direction so when the eighth-grade students ", unpublished ma thesis, College of education, the Islamic University in Gaza-Palestine.

23. Al-Hariqi, Saad (1985) how difficult the use of teaching students practical education. Seminar educational techniques between demands and challenges, the means and Technology Education Department, King Saud University, Riyadh, pp. 14-26.

24. Althobyani, Abid bin Abdullah (2009). The reality of contemporary techniques in mathematics teaching in middle school from the viewpoint of teachers, Center Ben for studies and research, Republic of Egypt. 
Annex 1.

Survey Questions:

\begin{tabular}{|c|c|c|c|}
\hline Questions & Agree & $\begin{array}{l}\text { Not } \\
\text { agree }\end{array}$ & $\begin{array}{l}\text { Somewhat } \\
\text { agree }\end{array}$ \\
\hline \multicolumn{4}{|l|}{$\begin{array}{l}\text { Do you think that using technology in learning mathematics help you to } \\
\text { understand mathematics better? }\end{array}$} \\
\hline \multicolumn{4}{|l|}{$\begin{array}{l}\text { Do you think that using teaching software helps students to understand } \\
\text { curriculum and then achieve the highest academic achievements? }\end{array}$} \\
\hline \multicolumn{4}{|l|}{$\begin{array}{l}\text { Do you think that changing math teaching methodology from "Traditional" to } \\
\text { "Modern" help students in study? }\end{array}$} \\
\hline \multicolumn{4}{|l|}{$\begin{array}{l}\text { Do using software in study encourage you to cooperate and participate with } \\
\text { colleagues in studying Math? }\end{array}$} \\
\hline \multicolumn{4}{|l|}{ Do you think there is lack of computers in the school? } \\
\hline \multicolumn{4}{|l|}{ Students don't like using the same teaching technique by teachers? } \\
\hline \multicolumn{4}{|l|}{$\begin{array}{l}\text { My academic achievements have been enhanced after a while of using teaching } \\
\text { software }\end{array}$} \\
\hline \multicolumn{4}{|l|}{ Math became interesting subject after using software in studying it. } \\
\hline \multicolumn{4}{|l|}{$\begin{array}{l}\text { Using teaching software save efforts and give me space to participate in } \\
\text { disunion and asking questions. }\end{array}$} \\
\hline Do Teachers use modern technology all the time? & & & \\
\hline
\end{tabular}

